\title{
Women's Language in the Movie Script of The Perks of being a Wallflower
}

\author{
Nunung Kurniaty \\ English Department - Faculty of Arts - Udayana University \\ [nunungkurniaty65@gmail.com]
}

\begin{abstract}
This study entitled Women's Languange in the movie script of The Perks of Being a Wallflower. This study is aimed at identifying the language features applied by women and finding out the functions of the language in the movie script.The theories applied in this study were the theory of women's language proposed by lakoff (1975). Lakoff states that women's speech was characterized by language features such as: the use hedges and fillers, tag question, rising or question intonation, empty adjective, precise color, intensifier, hypercorrect grammar, super polite form, the avoidance strong swear word, and emphatic stress. This study used the movie script of The Perks of Being a Wallfloweras the data source. The movie script was choosen as the data in this study because it contained women's language. The collected data were selected and put into categories of women's language features and their functions which were descriptively analyzed based on the theory applied.The finding of analysis shows that the women's language features found in this movie script include the use lexical hedges, tag question, rising or question intonation, empty adjective, intensifier, hypercorrect grammar, super polite form, and the avoidance strong swear word. Morever, the findings also show that the function of the women's language features show the speaker's strengthened assertion, the speaker's admiration for something, and to emphasize the speaker's judgment of something.
\end{abstract}

Keywords: sociolinguistics, women's language, women's language features and functions.

\begin{abstract}
Abstrak
Penelitian ini berjudul “Women's Language In The Movie Script Of The Perks Of Being a Wallflower". Tujuan dari penelitian ini adalah untuk mengidentifikasi fitur bahasa yang digunakan oleh perempuan dan juga menemukan fungsi dari masing-masing fitur bahasa yang digunakan oleh perempuan. Teori yang digunakan dalam penelitian ini adalah teori bahasa perempuan oleh Lakoff (1975). Data diperoleh dari naskah film "The Perks Of Being a Wallflower". Data yang terkumpul kemudian dianalisis secara deskriptif dengan menerapkan teori Lakoff (1975). Hasil analisis data menunjukkan bahwa ditemukan fitur bahasa yang digunakan oleh perempuan dalan naskah film ini, yakni: lexical hedges, tag question, rising or question intonation, empty adjective, intensifier, hypercorrect grammar, super polite form, and the avoidance strong swear word.
\end{abstract}


Kata kunci: sosiolinguistik, bahasa perempuan, fitur bahasa perempuan dan fungsinya.

\section{Background of the Study}

Language can be defined as a tool for communication. The existence of language takes an important role in society because by language people can communicate with one another and maintain relationship in social life. People interact in society through language conversation. According to Manser (2006), he divided the types of language in conversation itself into two groups. The first is Informal Language, it is defined as the language of ordinary or casual conversation that is a conversation between people who know one another and feel relatively. The second is Formal Language which is defined as the language official conversation that language agrees with the rules. The conversation feels relatively constrained and with best behavior.

Sociolinguistics explains how people speak differently in different social contexts.Men or women are the person who communicates each other. They do not speak in the same way. The differences of their conversations are in the content categories. When women talk to women, they usually talk about their feelings, their relationship and families. On the other hand, when men talk to men, they talk about sports, cars, and doing things. This study would analyze the features and their functions as represented by the women's characters in the movie script of The Perks of Being a Wallflower.The movie script of The Perks of Being a Wallflower was chosen since this movie script could show the phenomenon of the features women's language more completely to be analyzed.

\section{Problems of the Study}

The problems of this study are formulated as follows:

a. What kinds of women's language features are used in the movie script of The Perks of Being a Wallflower?

b. What are the functions of women's language features in the movie script of The Perks of Being a Wallflower?

\section{Aims off the Study}

The aims of this study are related to the problems proposed above, they are:

a. To find out the women'slanguage features used in the movie script of The Perks of Being a Wallflower.

b. To find out the functions of women's language features used in the movie script of The Perks of Being a Wallflower.

\section{Research Method}

In this section, there are four points of discussion covered including data source, method and technique of collecting data, method and technique of analyzing data, the last is method and technique of presenting the analysis.

\subsection{Data source}

The data of this study were taken from the observation script of the movie "The Perks of Being a Wallflower". The original script of the movie has been published in the internet. The script contains many conversations between women's and men's characters, and also women's and women's characters but 
this study only analyzes women's language in the movie.

\subsection{Method and technique of collecting data}

The data of this study were taken from the movie script of "The Perks of Being a Wallflower" by using documentation method. There weresome steps taken in collecting data. First, reading the script of the movie thoroughly to find out the sentence which could be conseidered as women's language features and their function. Then note taking of the data and ordering it into the list.

\subsection{Method and technique of analyzing data}

The collected data wereanalyzedusing the qualitative method. Based on the method and technique of collecting data above, after classifying the data based on the characteristic of women's language, the data were analyzed descriptively to find out the language features applied by the women and analyzed their functions using the theory proposed by Lakoff (1975).

\subsection{Method of presenting result of analysis}

The data of this study were analyzed by qualitative method, which means that the data were described or explained by words. Analyzing the data based on women's language features and their functions proposed by Lakoff (1975). The result of the analysis was presented descriptively by showing the types of women's language features and their functions in the sentence of the conversation, because the problem of this study needs description of analysis in order to make the utterance understandable for the readers.

\section{Analysis Of Women's Language Features And Functions}

The language features found in this movie script were the use of lexical hedges, the use of tag question, the use of rising intonation, the use of empty adjective, the use of intensifier, the use of hypercorrect grammar, the use of super polite form, and the use of avoidance strong swear words.

\subsection{Lexical Hedges}

Lakoff (1975:54) states hedges is one features that convey the sense the speaker is uncertain about what he (or she) is saying, or cannot vouch for the accuracy of the statement, such as 'well', 'you know', 'so fourth'. The functions to mitigate the possible unfriendliness or unkindness of a statement used for the sake of politeness and to show speaker's uncertainty about what she is saying, or cannot vouch for the accuracy of the statement.

Mary Elizabeth:Charlie... have you heard of the Sadie Hawkins dance?

Charlie :The one where the girl asks the guy.

Mary Elizabeth:Yeah. Well,

obviously, it's completely stupid and sexist. It's like, "Hey, thanks for the crumb." And normally, I'd just blowit off because school dances suck torture. But, you know, it's my last year, and... would you maybe want to go with me?

Charlie: You want to go with me?

Mary Elizabeth:I'm sick of macho guys. And you looked really cute in your costume. So, what do you say?

The women character, Mary Elizabeth used well in her utterance. She used the hedges well to express that her statement cannot vouch for the accuracy. Mary Elizabeth does not like Sadie Hawkins dance, such as, in Mary 
Elizabeth's utterance that she thinks that the Sadie Hawkins dance is stupid and sexist, Lexical hegdes you know is also used by Mary Elizabeth in this conversation. She used you know to show that she is uncertain about what she talked about.

Here it could be concluded that the function of hedges well and you know in the conversation was to show the speaker's uncertainty about what she is saying, or cannot vouch for the accuracy of the statement.

\subsection{Tag Question}

Tag question is a grammatical structure in which a declarative statement or an imperative is turned into a question by adding an interrogative fragment (the"tag") to request confirmation or disconfirmation of the statement from theaddressee. The functions are to give the addressee leeway, not forcing him to goalong with the speaker, make 'small talk', trying to elicit conversation from theaddressee, ask one's opinion in polite way in discussing personal feeling, avoidasserting herself in strong way, thereby to avoid coming in the conflict with theaddressee.

Charlie:That's sure a nice fire. Mary Elizabeth: Yeah. After I'm done being a lobbyist, Iwant to move to a house like this in CapeCod. That sounds nice, $\underline{\text { doesn't }}$ it? Charlie:Yeah.

In the conversation tag question doesn't it used by Mary Elizabeth above is used to show her lack confidence. It seems that the speaker has not convinced by what she said. She used tag question since she was not sure whether Charlie like it or not.

The function of tag question doesn't it in the conversation above is used to make a small talk or try to elicit conversation from the addressee. Women usually exploit tag question in order to keep conversation going.

\subsection{Rising Intonation}

Rising intonation is how people talk or ask something with a higher voice at the end of the sentence.The function of rising or question intonations is used when the speaker is seeking for confirmation, though at the same time speaker may be the only one who has the requisite information.

Candace's Friend:Candace... your brother's on the phone.

(Candace casually picks up the phone.)

Candace:Hello.

Charlie:Hey, Candace.

Candace:Charlie?

Charlie:Sam and Patrick left, and

um, I just can't stop thinking

something.

Candace: What?

Charlie:Candace, I killed Aunt Helen, didn't I?

She died getting my birthday present, so I guess I killed her, right?I've tried to stop thinking that, but I can't. She keeps driving away and dying over and over.

The conversation, between Candace and Charlie is on the phone. Candace knows that there was something happen to Charlie. The rising intonation "what?" was very useful to make him respond the question immediately. The intonation "what?" in her utterance also seems that she was worry about her brother.

The rising or question intonations is used when the speaker is seeking for confirmation, Therefore, the rising intonation in the conversation above used by the speakerto seek confirmation whether there was something happening to addressee. 


\subsection{Empty Adjective}

Empty adjective is used to the express approbation in terms of one's ownpersonal reaction, rather than by gauging the likely general reaction. The function is to show the speaker's approbation or admiration for something in her own way.

\section{Alice:It's gorgeous, Craig. What did you use? \\ Craig:Color film, but black and white paper forthe printing. My professor gave me an"A," but for the wrong reasons. Most ofthem are idiots. You'll see what I meanwhen you get to college. How were yourSAT's by the way?}

Alice:1150. I think I'll get into NYU. Craig:Yeah, I hope so.

In the conversation, Alice used the empty adjectives "gorgeous" in her utterance to show that she likes the black and white photo of naked Sam back on the wall of Craig's loft apartment.She used the empty adjectives in order to indicate the approbation for something but it is only used to convey the emotional reaction rather than to give specific information. The use of empty the adjective gorgeous in her utterance is to express her admiration for Craig's photo.

\subsection{Intensifier}

Intensifier is the emphasis on the words spoken by the speaker. The function is to strengthen an assertion shown through women's feeling about something as they do not know how strong the feeling is.

Mother:You must be Mary Elizabeth. It's so good to meet you.

Mary Elizabeth:You, too, Mrs. Kelmeckis.
Father:Charlie tells me you're a Buddhist.

Charlie's mother used intensifier so in her utterance to show her feeling to Mary Elizabeth. She was happy that she met Mary Elizabeth for the first time. Intensifier can be used to strengthen an assertion. It is also used to hedge on one's feelings and to show strong emotions.

In addition, the intensifier so functions to show that the speaker (Charlie's mother) had a strong feeling on her assertion. The use of intensifier so showed Charlie's Mother strong emotions that she was happy to meet Mary Elizabeth.

\subsection{Hypercorrect Grammar}

Hypercorrect grammar is standard grammar used by the speaker while they are speaking. It functions to show politeness and at the same time create a distance to the addressees.

\section{Sam:That first night, I had grilled}

stickies. It was so good. You have to visit in the Fall. We'll have some.

Okay?

Charlie:Definitely.

Patrick:Sorry, Sam. Charlie has a breakdown scheduled for October.

She used hypercorrect grammar I had grilled. The sentence I had grilled in Sam utterance was considered past perfect tense and the rule is: $\mathrm{S}+\mathrm{had}+$ past participle. She used hypercorrect grammar in her utterance since she wanted to speak politely. This utterance called hypercorrect grammar since it contains sentence structure in the conversation.

So, the conversation could be seen that the function of the hypercorrect grammar is to show politeness and at the same 
time to create a distance to the addressees.

\subsection{Superpolite Form}

Super polite form is uttered to make the listeners feel comfortable, and to hold on well the relationship. It is often suggested that politeness is developed by societies in order to reduce friction in personal interaction.

Mother:You must be Mary Elizabeth. It's so good to meet you.

Mary Elizabeth:You too,
Mrs.Kelmeckis.

The conversation above shows the use of superpolite form Mrs. by Mary Elizabeth in her utterance. The use of title Mrs. before the addressee's last name shows that she speaks in a polite way and creates a distance.

The use of Mrs. functions as the indicator that Mary Elizabeth speaks in a polite way and creates the distance to Mrs. Kelmeckis as Charlie's mother. Hence, she must speak in polite way because she does not know well who Mrs. Kelmeckis and she does not have close relationship with Mrs. Kelmeckis.

\subsection{Avoidance of Strong Swear Words}

Lakoff (1975:10) states that women often avoide using the strong swear word or strong expletive (such damn, shit or one of many other words). The function of how strongly one allows oneself to feel about something so the strength of emotion conveyed in sentence corresponds to the strength of particle

Sam: $\underline{\text { Oh, my God. They're playing good }}$ music.

Patrick:Holy shit. They are! They're playing good music!

Sam :Living room routine?

Patrick:Living room routine!
The conversation, Sam use $O h$, my God in her utterance shows how she got surprised by the music. Sam was very happy so she runs to the center on the floor and she starts dancing. The most form of swear word form found in the data is the word God used by the women characters in the movie.

The function of the words Oh, My God spoken by Sam was to show how strongly she allowed herself to feel about something, so the strength of the emotion conveyed in a sentence corresponds to strength of the particle in her utterance; she showed how surprised she was.

\section{Conclusion}

The topic of discussion in this study was women's language in term of women's linguistic features and their functions.There are eight features of women language, as identified by Robin Lakoff (1975). They are lexical hedges, the use of tag question, the use of rising intonation, the use of empty adjective, the use of intensifier, the use of hypercorrect grammar, the use of super polite form, and the use of avoidance strong swear words. All of those features were found in the movie script entitled "The Perks of Being a Wallflower" and used by the some female characters in this movie.

\section{Bibliography}

Cbhosky, Stephen. 2012. The Perks of Being a Wallflower. Summit Entertainment. Available form: http://www.imsdb.com/scripts/Perk $\underline{\mathbf{s}}$

of-Being-a-Wallflower,-The.html

Lakoff, Robin. 1975. Language and Women's Place. New York: Harper \& Row 
Manser, Martin H. 2006.Guide to Style:

Essential Guide to The Basic of Writing Style. Facts on File.Inc.

Pratiwi, Desak Putu Eka. 2007. The Analysis of Women Language in Oprah Winfrey Talk Show. Denpasar: FS Udayana University

Rusady, Ni Made Yuliantari. 2010. Women Language in the movie "Pride and Prejudice". Denpasar: FS Udayana University. 